\title{
Alexander of Telese's Encomium of Capua and the Formation of the Kingdom of Sicily
}

DOI:

10.1111/1468-229X.12374

\section{Document Version}

Accepted author manuscript

Link to publication record in Manchester Research Explorer

\section{Citation for published version (APA):}

Oldfield, P. (2017). Alexander of Telese's Encomium of Capua and the Formation of the Kingdom of Sicily. History, 102(350), 183-200. https://doi.org/10.1111/1468-229X.12374

\section{Published in:}

History

\section{Citing this paper}

Please note that where the full-text provided on Manchester Research Explorer is the Author Accepted Manuscript or Proof version this may differ from the final Published version. If citing, it is advised that you check and use the publisher's definitive version.

\section{General rights}

Copyright and moral rights for the publications made accessible in the Research Explorer are retained by the authors and/or other copyright owners and it is a condition of accessing publications that users recognise and abide by the legal requirements associated with these rights.

\section{Takedown policy}

If you believe that this document breaches copyright please refer to the University of Manchester's Takedown Procedures [http://man.ac.uk/04Y6Bo] or contact uml.scholarlycommunications@manchester.ac.uk providing relevant details, so we can investigate your claim.

\section{OPEN ACCESS}




\section{Alexander of Teleseôs Encomium of Capua and the Formation of the Kingdom of Sicily ${ }^{1}$}

\section{Paul Oldfield}

(This article accepted for publication by History: The Journal of the Historical Association on 01/11/16)

In 1130 Roger II Count of Sicily took the momentous step of claiming a novel royal title. His newly-created Kingdom of Sicily sought to encompass, under the rule of one monarchy, Rogerôs own County of Sicily and the South Italian mainland territories of the Duchy of Apulia and Calabria (including the lands of the former Lombard Principality of Salerno) and the Principality of Capua. In the decade preceding the creation of the kingdom, Roger had gradually become the pre-eminent figure in the landscape of South Italian power politics, and this pragmatic reality formed the nucleus of his royal aspirations. From a stable base in Sicily, he had formally acquired the mainland title of duke of Apulia in 1128 following the death without heir of his Hauteville relative, Duke William, in 1127. Rogerôs ascent had met with fierce opposition from several South Italian mainland nobles and cities, both in 1127-28 when he sought the Duchy of Apulia, and once again from 1130. The papacy too had been reluctant to support Rogerô pretensions vis-à-vis his ducal claims in Apulia, and while Pope Anacletus II acknowledged Rogerôs royal title in 1130, a papal schism was in force, and the rival candidate, Innocent II, was openly opposed to the new kingdom. The German Emperor, with long-standing claims over the Italian peninsula, also refused to accept the existence of the new kingdom. Rightly so, several parties were fearful of the would-be kingôs potentially

\footnotetext{
${ }^{1}$ I would like to express my gratitude to Professor G. A. Loud who kindly commented on an early draft of this article and also to the British Academy, for the award of a Mid-Career Fellowship which enabled the research for this piece.
} 
extensive power. Conflict would endure until 1139 when Roger overcame the last remnants of resistance.

Scholarship has devoted much space to identifying Rogerô royal strategy in its embryonic and contested state of the 1130s $\ddot{i}$ with views ranging from tyrannical authoritarianism to control via negotiation and consensus $\ddot{i}$ and also to pinpointing some of the major turning points which led to the creation of the Sicilian monarchy; the latter include Rogerô significant defeat at the Battle of Nocera in 1132, his prolonged illness and the death of his wife in the winter of 1134-5, the German imperial invasion of 1137, and Rogerô counterattack which led to the fall of Naples in 1138, the recapture of Bari in 1139 and the forced submission of the pope at Mignano in the same year. ${ }^{2}$ This article aims to contribute to this body of scholarship on the formation of the monarchy by examining an undervalued passage in the Ystoria Rogerii Regis Sicilie Calabrie atque Apulie of Alexander of Telese, a contemporary work of indispensable value for any understanding of the formation of a monarchy that changed the shape of South Italian history thereafter. ${ }^{3}$ Only one other narrative

\footnotetext{
${ }^{2}$ See for example the seminal contributions in Società, potere e popolo nell'età di Ruggero II. Atti delle terze giornate normanno-sveve, Bari, 23-25 maggio 1977 (Bari, 1979); D. Clementi áHistorical commentary on the đáibellusô of Alessandro di Teleseô in Alexandri Telesini Abbatis Ystoria Rogerii Regis Sicilie Calabrie atque Apulie, ed. L. de Nava (Rome, 1991) [henceforth: Alex. Tel.], pp. 175-346; H. Houben, Roger II of Sicily: a ruler between east and west, trans. G. A. Loud and D. Milburn (Cambridge, 2002); M. Caravale, Il regno normanno di Sicilia (Rome, 1966); G. A. Loud, ántroductionôin his Roger II and the Creation of the Kingdom of Sicily (Manchester, 2012); P. Oldfield, City and Community in Norman Italy (Cambridge, 2009), pp. 55-81; P. Oldfield, órhe Bari Charter of Privileges of 1132: articulating the culture of a new Norman Monarchyô Historical Research 88 (2015), 577-98.

${ }^{3}$ I follow the title of Alexanderôs work used by De Nava in the modern edition (see footnote above), although Alexander simply called it a libellus: Alex. Tel., p. 89. The English translation is in Loudô Roger II and the creation of the Kingdom of Sicily, p. 126 (đ́ittle bookô; henceforth when using Alexanderôs work I will cite the
} 
account, Falco of Beneventoôs chronicle which was more hostile to Roger II, can match Alexanderô in its significance for this period of South Italian history. The passage in question, an encomium of Capua, points towards Rogerôs capture of that city in the summer of 1134 as a pivotal event in the political and ideological formation of the new kingdom. It is an event which demands a more detailed analysis than it has hitherto received within the historiography for it suggests the need to shift the focus, both temporally and geographically, within the current picture of the kingdomôs formation.

The passage, on which this article pivots, occurred in Book II chapter 66 of the chronicle by the Abbot Alexander of the Campanian monastery of San Salvatore di Telese. To understand that passage it is, of course, vital first to appreciate the authorô influences and objectives. Alexanderôs monastery was situated in the Principality of Capua around 30km north-east of Capua itself. It was possibly founded just before 1075, perhaps by the younger brother of Richard I, the first Norman Prince of Capua. This, combined with evidence for the early architectural design of the monastery, and the presence of a monk of Bec who had been a pupil of St Anselm, as abbot in c.1100, suggests that San Salvatore was in origin a Norman house. Alexander, who had died or been replaced as abbot by 1143, produced his work in late 1135 or early $1136 .{ }^{4}$ It recorded key events in Rogerôs life, primarily from 1127 , and covered the foundation of the kingdom of Sicily in 1130 and the early conflicts that ensued on the

Latin edition first - Alex. Tel. - followed by Loudôs translation in parentheses - (Roger II); see also Clementi, đ́Historical commentaryQ̂ pp. 177-9.

${ }^{4}$ Loud, đ́ntroductionô p. 52; L. R. Cielo, L'abbaziale normanna di S. Salvatore de Telesia (Naples, 1995). Unfortunately little is known about the history of the abbey in the twelfth century, although the discovery of a poem in 46 Leonine hexameters, produced by a monk of San Salvatore during the reign of Roger II (1130-54), does suggest that a certain level of intellectual accomplishment was achieved there: see D. Frioli, ónna poesia di S. Salvatore di Telese al tempo di Ruggero IIô Studi Medievali, 21, $3^{\text {rd }}$ ser. (1980), 855-9. 
mainland up to around the end of 1135 , at which point the work finished apparently in anticipation of Rogerôs submission of Naples in 1136 and the kingố expected final success (which turned out to be premature).

The abundant scholarship on Alexanderô Ystoria stresses different facets of the agenda pursued within it, but all situate a palpable pro-royal stance at its core. For Graham Loud, for example, Alexanderôs was a work eulogising a new monarch who was ádoing Godô work in bringing peace to southern Italyôand this was reiterated in the prophetic dreams at the end of Book IV which in varying guises foretold Rogerôs inevitable, divinely-ordained triumph. ${ }^{5}$ It might also, following Dione Clementi, have attempted to convince Rogerô new subjects, particularly within the cities of Campania, of the benefits of the law and order that the king could guarantee. Indeed, Clementi argues that the work, which Alexander termed a libellus, should be viewed as a political pamphlet. ${ }^{6}$ Caterina Lavarra likewise stressed the political agenda within a work which presented Roger as an instrument of divine justice. ${ }^{7}$ Edoardo DôAngelo suggested that the central theme was óf the legitimacy of the violence (of Roger), conceived strictly linked to the yearning for a peace (in the sense precisely of a pax Rogeriana), opposed to the anarchy of the baronsô ${ }^{8}$ This was a theme nuanced more recently still by Eleni Tounta, who argued that Alexander was attempting to legitimise a new political culture based on Rogerôs exercise of the terror regius, a notion which encompassed physical

\footnotetext{
${ }^{5}$ Loud, ántroductionô p. 53.

${ }^{6}$ Clementi, áHistorical commentaryô pp. 177-9, 191-2; E. DôAngelo, Storiografi e cronologi latini del Mezzogiorno normanno-svevo (Naples, 2003), p. 126.

${ }^{7}$ C. Lavarra, ó́pazio, tempi e gesti nellôó óstoria Rogeriiôdi Alessandro di Teleseô Quaderni Medievali 35 (1993), 79-100.

${ }^{8}$ DôAngelo, Storiografi, p. 31.
} 
violence, justice and peace in order to express the q́rimacy of royal powerô ${ }^{9}$ Other scholars identified the workôs panegyric style as an insincere façade behind which a didactic text or a speculum principis functioned. For Massimo Oldoni, the work was not even solely aimed at Roger II but went further to provide a model of good rulership and virtuous Christian comportment founded on justice, prudence and humility. ${ }^{10}$ The textôs concluding Alloquium addressed Roger and reminded him of Godôs role in his success, and, through several intertextual allusions, offered Biblical and Roman exemplars of good (David, Solomon, Constantine, possibly Alexius Comnenus, and Octavian,) and bad (Saul, Domitian, Maximillian and Octavian again) rulership. ${ }^{11}$ The muted role of the papacy and the limited presence of bishops in the Ystoria also suggested that Alexander viewed the monarchyô path to success via an alliance with monasticism, as Enzo Sipione particularly suggested. ${ }^{12}$ The underpinning message, in its various shades of interpretation, presented Roger as guarantor of peace and vessel of a divine plan.

The standpoint displayed within Alexanderôs work then shows him to be an avowed partisan of the king. We might go so far as to say, as Oldoni did, that he was part of the royal

\footnotetext{
${ }^{9}$ E. Tounta, óTerror and territorium in Alexander of Telese's Ystoria Rogerii regis: political cultures in the Norman kingdom of Sicilyô Journal of Medieval History 40 (2014), 142-58 (quote at p. 152).

${ }^{10}$ M. Oldoni, óRealismo e dissidenza nella storiografia su Ruggero II: Falcone di Benevento e Alessandro di Teleseô in Società, potere e popolo nell'età di Ruggero II, pp. 271, 275-8, 281-2.

${ }^{11}$ Alex. Tel., Alloquium, pp. 89-92 (Roger II, pp. 127-29); DôAngelo, Storiografi, pp. 125-33.

${ }^{12}$ See E. S. Sipione, đ́potesi sulla "Vita di Ruggero II" dell'abate Alessandro di Teleseô Siculorum Gymnasium 20 (1967), pp. 281, 284; DôAngelo, Storiografi, pp. 132-33; Oldoni, đ́Realismoô p. 271. On the papacy and Roger II, see R. Elze, óRuggero II e I papi del suo tempoôin Società, potere e popolo nell'età di Ruggero II, pp. 27-39 ; and on the Sicilian monarchy more generally see G. A. Loud, The Latin Church in Norman Italy (Cambridge, 2007), pp. 255-339
} 
establishment. ${ }^{13}$ Besides being geographically close to several events described, and having personally met the king, Alexander also seems to have had access to information from individuals involved in some episodes, and to certain official documents. He also probably obtained information from Roger IIôs sister Matilda. ${ }^{14}$ Alexanderôs account was produced on the request of Matilda, who was also the wife of Count Rainulf of Caiazzo, a leading baron of Campania and one of Rogerôs foremost opponents in the struggle to establish the new monarchy. Like most monastic authorôs Alexander was concerned with the maintenance of public peace, and supported Roger to this end, but he also clearly hoped his literary labours would inspire patronage of his monastery. ${ }^{15}$ In the Ystoria, Roger II is recorded visiting the monastery amid great ceremony before the seizure of Capua in 1134 . He was received into the monasteryôs confraternity and pledged to increase its property. ${ }^{16}$ Later on, Roger visited the monastery again, made more specific promises of grants to San Salvatore, and his son Anfusus was also welcomed into the monastic confraternity. ${ }^{17}$ Alexander gleefully recorded how in 1135 he sent his prior to meet the king at Salerno who came good on his promises and bestowed on the monarchy sufficient silver for a chalice and two thuribles as well as confirmation of ownership of a mountain near to San Salvatore. Consequently, Alexander ómmediately ordained that every day at the morning mass in the convent there should be a solemn prayer for the life and safety of the king and his sonsô and hoped that this

\footnotetext{
${ }^{13}$ Oldoni, đ́RealismoQ̂ p. 269.

${ }^{14}$ Clementi, đ́Historical commentaryô pp. 213-23.

${ }^{15}$ Clementi, ơHistorical commentaryô p. 192. In the Alloquium Alexander noted how lavishly Virgilôs two verses in praise of Octavian was rewarded by the latter who conferred on the poet rule over Naples and all of Calabria, Alex. Tel., Alloquium, p. 89 (Roger II, p. 127).

${ }^{16}$ Alex. Tel., II.65 pp. 54-5 (Roger II, p. 102). For Rogerôs relations with San Salvatore, see also Sipione, 'Ipotesiô pp. 281-4.

${ }^{17}$ Alex. Tel., III.29-30 pp. 75-6 (Roger II, p. 117).
} 
memorialisation of such good deeds would encourage comparable actions in the future. ${ }^{18}$ In stark contrast, Rainulf of Caiazzo was criticised for despoiling the monastery in order to prolong his conflict with Roger. ${ }^{19}$ But, as Loud and Clementi noted, Alexander walked a fine line in his work, for Rainulf was depicted sympathetically and as a áloughty warriorô(árat acerrimusô, and was never unequivocally condemned in the Ystoria, while the resistance of the kingôs other chief opponent, Prince Robert II of Capua, was mostly presented in a neutral, even rational manner. ${ }^{20}$ This might reflect the authorôs willingness to respect the sensitivities of Roger II $\hat{a}$ sister and his hope that Rainulf, a formidable force in the vicinity of the monastery, would eventually submit, along with Alexanderô lingering atavistic empathy towards a princely dynasty that had loomed large in the monasteryô history. ${ }^{21}$

Thus we might conclude that Alexander reflected within his work a set of affinities based around a triad of interests: (1) The monarchy: his proximity to court circles suggests that he had access to information close to Roger (who visited his monastery at least twice), and thus reflected elements of the royal position, and/or had the capability of filtering some of the messages within his work to Roger or his advisors which Alexander must then have pitched appropriately for that audience; (2) The Principality of Capua: composed from within the Principality, Alexanderôs work reflects aspects of the Campanian elitế perception of the importance of Capua in the political configuration of the South Italian mainland; (3) The monastery: as abbot of a monastic community, Alexanderô work demonstrates a monastic

\footnotetext{
${ }^{18}$ Alex. Tel., III.36 pp. 78-9 (Roger II, p. 120).

${ }^{19}$ Alex. Tel., III.30 p. 76 (Roger II, p. 117).

${ }^{20}$ The quote at Alex. Tel., II.31 p. 37 (Roger II, pp. 88-9), and see other examples at Alex. Tel., II.15 p. 30 , II.17

p. 31, III.10 pp. 64-5; (Roger II), pp. 82-3, 83-4, 108-09; Clementi, áHistorical commentary, pp. 199-200.

${ }^{21}$ Loud, đ́ntroductionô p. 53. Moreover, the probable founder of the monastery, Count Rainulf I, was grandfather of Rainulf of Caiazzo, perhaps another reason for Alexanderô careful treatment of the latter.
} 
understanding of the formation of a new regnum. A work with such poly-focal attributes should then be understood as something more than simple royal panegyric, and it is this multi-layered perspective which is voiced in Alexanderô encomium of Capua and which transforms it into a highly resonant tableau of the wider work. Although only one fourteenthcentury manuscript of the work survives, suggesting limited distribution of the work, one must remember that this information only tells us so much. ${ }^{22}$ Indeed, works that were heavily used or circulated were more prone to damage and loss, and, according to Oldoni, the Ystoria displays signs of án oral narratabilityôpossibly indicating its performative function for the monastic community at the very least. ${ }^{23}$ In any case, the key point for this study is that Alexanderôs text can be read as an embodiment of contemporary ideas and influences drawn from the socio-political and cultural worlds within which the monastery was embedded, and thus could serve as what scholars term á site of memoryôor áultural artefactôfor crucial events in the $1130 \mathrm{~s}^{24}$

The literature on the Ystoria has tended to focus, rightly so, on some key passages redolent with a symbolic and didactic tone: above all the work $\hat{Q}$ Prologue, the series of prophetic dreams at the end of Book IV, and the closing Alloquium addressed to Roger himself. Clementiô exhaustive analysis nuanced this and identified six places in which Alexander interrupted, or digressed from, his narrative. ${ }^{25}$ I would propose an important seventh:

\footnotetext{
${ }^{22}$ Loud, đ́ntroductionô pp. 54-5; Clementi, ótistorical commentaryô p. 177.

${ }^{23}$ Oldoni, ĆRealismoQ̂ pp. 278-9. Tounta, óTerror and territoriumô p. 157 argues for an audience including local elites and the royal court.

${ }^{24}$ See the useful discussion on texts as cultural artefacts in the introduction of M. Bull and D. Kempf (eds), Writing the Early Crusades: text, transmission and memory (Woodbridge, 2014), pp. 1-8. See also L. Ashe, Fiction and History in England, 1066-1200 (Cambridge, 2011), p. 2.

${ }^{25}$ Clementi, óHistorical commentaryâ pp. 181-91.
} 
Alexanderô largely-overlooked encomium of Capua, a passage of praise which was inserted in Bk.II chapter 66 immediately after the record of the conquest of the city. The passage reads as follows:

Three days later, he [Roger II] arrived very early in the morning at the most illustrious city of Capua and received the surrender of its citizens and of all the magnates of the Terra di Lavoro. This city is indeed a real metropolis, and as is recorded from ancient times was called by this name either because it is the capital of Campania or because it is surrounded by a long and wide plain or, so it seems to some people, is called Capua from its founder Capy. It is a most extensive city, fortified by a circuit of walls and towers, and the River Volturno flows through the middle of these walls. On this river there are many water mills tied together with hempen ropes. A bridge of great size and wonderful workmanship has been built across it, which allows people to go in an out from one part of the city to the other where there is an extensive suburb. And it is a city overflowing with [the fruits of] Ceres and Bacchus, and meat as well as with all sorts of other merchandise, nonetheless a great many people frequent it. What is more, it is above all distinguished by its dignity as the princely capital. ${ }^{26}$

This praise of Capua follows the ancient literary template of the laus civitatis. Classical rhetorical manuals by the likes of Priscian and Menander Rhetor indicated how praise of a city should be set out. Various qualities were recommended for praise. These could include information on the cityôs foundation and history (including the deeds of famous citizens, particularly saints), the fertility of the surrounding landscape, the cityôs size and topography, including its key buildings (often fortifications, gates, churches, bridges), and commercial

\footnotetext{
${ }^{26}$ Roger II, p. 102. The Latin: Alex. Tel. II.66 p. 55: Post tertium vero diem, summon mane secedens, Capuam illustrissimam urbem civibus eius cunctisque terre Laboris magnatibus sese dedentibus recepit; que videlicet urbs metropolis existens, idcirco, ut ab antiquis traditur, tale sortita est vocabulum, vel quia caput Campanie est, vel quia campi planitie longa lataque giratur, seu, ut quibusdam videtur, a Capi conditore suo Capua dicitur. Est quidem ampliori situ capacissima, munibus turribusque in circuito munitissima; cuius quoque muralem ambitum Vulturnus flumen medium preterfluit; intra cuius fluenta plurima in aquis supernatantia molendina funibus cannabineis innexa consistunt. Pons quoque mire magnitudinis miroque opere constructus in ipso amne extat fundatus, qui intrantibus et exeuntibus meatum prebens, ab una parte urbe, ab alia vero burgo valde prolixo obviatur. Sed et Cerere Baccho carnisque edulio, nec non diversis commerciis civitas uberrima, populosa nihilominus frequentatur accessu; et, quod maius est, principali constat dignitate precellens.
} 
activities. ${ }^{27}$ These broad guidelines continued to be followed in the medieval period, although inevitably each case of panegyric was adapted to a localised context and the specific city in question, as Alexander himself clearly did here.

But why suddenly insert an encomium of Capua at this point? It is out of step with the narrative tone of the work, with its rapid and seemingly linear chronological approach, and at no other place in the Ystoria does Alexander really utilise the model. This is despite having every opportunity to do so, for example when outlining Rogerô subjugation of key cities such as Salerno and Bari. ${ }^{28}$ The closest Alexander offers was a later short passage on the attempted blockade of Naples which spoke of the cityôs antiquity, impregnability and how it was granted to Virgil by the emperor Augustus. ${ }^{29}$ Given that in the Alloquium Alexander uses

\footnotetext{
${ }^{27}$ For urban panegyric and the laus civitatis genre see: J. K. Hyde, óMedieval Descriptions of Citiesô Bulletin of the John Rylands Library, xlviii (1965-66), 308-40; C. J. Classen, Die Stadt im Spiegel der Descriptiones und Laudes Urbium in der antiken und mittelalterlichen Literatur bis zum Ende des zwölften Jahrhunderts (Hildesheim, 1980); E. Occhipinti, đ́mmagini di città. Le Laudes Civitatum e la rappresentazione dei centri urbani nellâtalia settentrionaleô Società e Storia 14 (1991), 23-52; G. Fasoli, đ́a coscienza civica nelle ñLaudes Civitatumòô in her Scritti di storia medievale, (eds) F. Bocchi, A. Carile, A. Ivan Pini (Bologna, 1974), 293318; P. Zanna, óDescriptiones Urbium and Elegy in Latin and Vernaculars in the Early Middle Agesô Studi Medievali, 32, 3rd ser. (1991), 523-96; H-J. Schmidt, óSocietas Christiana in Civitate: Städtekritik und Städtelob im 12. und 13. Jahrhundertô Historische Zeitschrift, 257 (ii) (1993), 297-354; J. S. Ruth, Urban Honor in Spain. The Laus Urbis from Antiquity through Humanism (Lewiston, 2011); P. Oldfield, Urban Panegyric and the Transformation of the Medieval City, 1100-1300 (Oxford, forthcoming).

${ }^{28}$ Alex. Tel., I.5-6 pp. 8-9, II.20 p. 32 (Roger II, pp. 66-7, 84).

${ }^{29}$ Alex. Tel., III.19 pp. 69-70 (Roger II, p.112). There also was a short passage of praise of Aversa but which claimed its inhabitants were vice-ridden and thus their city was deservedly destroyed by Roger, pp. 109-10. For Naplesô Virgilian legends/associations see D. Comparetti, Vergil in the Middle Ages, trans. E. F. M. Benecke (London, 1895; reprinted, 1966); P. Oldfield, Sanctity and Pilgrimage in Medieval Southern Italy (Cambridge,
} 
the example of Augustusôgift of Naples to Virgil as recompense for the latterô composition of panegyric, we might need to view this briefer urban encomium as certainly pointing towards the significance of the city for Rogerô plans, but more so as another plea by Alexander for royal reward for his literary project. Again, it demonstrates that when panegyric appeared it was not as a mere rhetorical flourish to accompany the rest of the text. It almost always served as a microcosm of aspects of the wider narrative, projecting a message of fundamental importance, one that often underpinned the remainder of the work. ${ }^{30}$

All of this then indicates that the reader was supposed to take particular note of the passage on Capua, or that it served to implicitly convey something of notable importance. Indeed, there are other examples of the careful emplotment of urban encomium in South Italian literary works, where emphasis on the praiseworthy attributes of cities magnified a wider narrative of significant transition or an atmosphere of despair. In some instances we find praise of cities which had recently fallen to a new ruler; their virtues reflective of those of their conqueror and the legitimacy of that takeover. In southern Italy, William of Apuliaôs epic Gesta Roberti Wiscardi (Deeds of Robert Guiscard) of the late-1090s included descriptions of the cities of Salerno and Amalfi which show traces of the laus civitatis model. Both cities were key centres of alternative political authority in late-eleventh century southern Italy, and they are praised in the Gesta Roberti immediately after news of their capture in 1076 by the Norman Duke Robert Guiscard. ${ }^{31}$ The work was dedicated to Duke Roger, the

2014), pp. 215-16; G. Vitolo, L'Italia delle altre città. Un imagine del Mezzogiorno medievale (Naples, 2014), pp. 215-18.

${ }^{30}$ See M. Otter, ófunctions of Fiction in Historical Writingâ in N. Partner (ed.), Writing Medieval History (London, 2005), p. 118.

${ }^{31}$ Guillaume de Pouille, La Geste de Robert Guiscard, ed. and trans. M. Mathieu (Palermo, 1961), Bk.III, verses 470-85, p. 190 and The Deeds of Robert Guiscard, trans. G. A. Loud, available at 
son and successor of Guiscard. Rogerô rule was repeatedly challenged and these urban encomia fit into the wider strategy of a work attempting to stabilise and legitimise by association with the glorious deeds of his father. Other examples can be found in the twelfth century. Falco of Beneventô̂ pointed praise of his native city during the 1119 translation of relics might be viewed as part of his broader scheme condemning urban factionalism. ${ }^{32}$ And in the 1190s, when the Staufen emperor Henry VI attempted to conquer the Kingdom of Sicily, two works employed urban economia. One, an extended letter, written quite possibly by the so-called Hugo Falcandus, lamented the imminent Staufen invasion and praised a number of Sicilian cities as part of his call for unified resistance and to demonstrate what would be lost. ${ }^{33}$ The other, the poem entitled Liber ad Honorem Augusti, was written by Peter of Eboli to record and praise the invasion of the Staufen emperor Henry VI. ${ }^{34}$ Short laudatory

http://www.leeds.ac.uk/arts/downloads/file/1049/the_deeds_of_robert_guiscard_by_william_of_apulia, p. 39; On William of Apulia, see E. Albu, The Normans in their Histories: propaganda, myth and subversion (Woodbridge, 2001), pp. 106-44

${ }^{32}$ Falcone di Benevento, Chronicon Beneventanum, ed. E. DôAngelo (Florence, 1988), pp. 46-52 (English translation in Roger II, pp. 154-6). For more on critiques of urban disorder see Oldfield, Urban Panegyric, chapter 3.

${ }^{33}$ The Letter is found attached to the manuscript of the chronicle by the so-called ớHugo Falcandusô It is edited in La Historia o Liber de Regno Sicilie e la Epistola ad Petrum Panormitane Ecclesie Thesaurium, ed. G. B. Siragusa, pp. 169-86 and translated into English in the appendix of The History of the Tyrants of Sicily by 'Hugo Falcandus', 1153-69, trans. G. A. Loud and T. E. J. Wiedemann (Manchester, 1998), pp. 252-63.

${ }^{34}$ Petrus de Ebulo, Liber ad Honorem Augusti sive de rebus Siculis, ed. T. Kölzer and M. Stähli (Sigmaringen, 1994). There is also now an English translation: Book in Honor of Augustus (Liber ad Honorem Augusti) by Pietro da Eboli, trans. G. Hood (Tempe: Arizona Center for Medieval and Renaissance Studies, 2012). 
depictions of South Italian and Sicilian cities occurred in the poem at precisely the point at which they were being taken over by foreign invaders in the early-1190s. ${ }^{35}$

Why might Capua have been so important that it compelled Alexander to pen a distinctive passage of praise? Firstly, the city was clearly a major urban and political reference point for the part of Campania in which San Salvatore di Telese was situated. This in itself meant Alexander was more likely to praise the virtues of this city over any other. The clamour of events in the Princely capital would inevitably resound more loudly in Alexanderôs monastery than those emanating from any other city. ${ }^{36}$ But Alexander was not merely viewing events through a distorted local optic. He rightly perceived in Capuaôs fate much deeper ramifications. Throughout the 1130s, Rogerô attempts to subsume the Principality of Capua under the umbrella of monarchy were particularly controversial. Control of the other component parts of the putative new kingdom was less contentious. The Duchy of Apulia and Calabria had previously been ruled by members of Rogerô Hauteville family, and indeed Roger put forward that familial link when he overcame opposition to become duke of these lands in 1128. Likewise, since its conquest in 1077 by Robert Guiscard, Rogerôs uncle, the Lombard Principality of Salerno had been subsumed within the Duchy of Apulia and

\footnotetext{
${ }^{35}$ Petrus de Ebulo, Liber, 97v lines 56-63; 108v lines 354-9; 121v lines 773-82. The work also praises cities visually for it is accompanied by illustrations in which cityscapes feature prominently. Capua, Naples, Palermo, Salerno and Messina are among the cityôs depicted, always with magnificent fortifications, and often filled with public buildings and crowded spaces: Liber ad Honorem Augusti, 97r, 98r, 108r, 109r, 110r, 111r, 112r, 113r, 115r, 116r, 117r, 120r, 122r, 123r, 124r, 132r, 134r.

${ }^{36}$ That the monastery gravitated towards events in Capua is also shown by the first recorded appearance of Stephen, Alexanderôs successor as abbot, in November 1143 as a witness, in the presence of Roger II, at a royal court at Capua: Rogerii II Regis Diplomata Latina, ed. C. Brühl (Codex Diplomaticus Regni Siciliae, Ser. I.ii (I)), no. 59, p. 169.
} 
Calabria. Its incorporation into a larger entity governed by a Hauteville also provoked far less discontent.

The Principality of Capua by contrast had been, since 1058, under the control of the descendants of another Norman dynasty, the Quarrels. At least two Quarrels had married members of the Hauteville family, but they steadfastly nurtured the independence of a principality that had existed since the Lombard era, and indeed continued to model its governance on Lombard traditions. Mindful of the threat posed to his principality by the combination of Sicily and Apulia in the hands of one ruler, Prince Robert II had opposed Rogerô acquisition of the Duchy of Apulia in 1128. When in that year Roger finally received Pope Honorius IÎ̂́ recognition of the ducal title at the Treaty of Benevento, according to Falco it stipulated that Roger should not seize the Principality of Capua. ${ }^{37}$ However, Pope Anacletus IIôs charter of 1130 recognising the foundation of the kingdom controversially subjugated Capua to Hauteville rule. ${ }^{38}$ It confirmed the constituent parts of the new kingdom ï Sicily, Apulia (which comprised the Principality of Salerno too), and Calabria $\ddot{I}$ and then dealt with zones outside of the Hauteville sphere. As well as granting the ćnonour of Naples and its possessionsôand the aid of the Beneventans, it stated: óve grant to you and your heirs and authorise [to rule] the principality of Capua with all its appurtenances, as the princes of

\footnotetext{
${ }^{37}$ Falcone di Benevento, Chronicon, p. 102 (Roger II, p. 182), although E. M. Jamison, ÓThe Noman Administration of Apulia and Capua more especially under Roger II and William I, 1127-1166ô Papers of the British School at Rome 6 (1913), pp. 211-481 [reprinted as a separate volume, Aalen, 1987], p. 237 suggests that, while the Principalityô independence was to be respected, its prince owed homage to Roger, and Alexander of Telese indicated that the prince submitted to Rogerô lordship: Alex. Tel. I.24 pp. 20-1 (Roger II, p.77)

${ }^{38}$ Translated in Roger II, pp. 304-06.
} 
the Capuans have held it in the past and [as they do] at the moment. $\hat{O}^{9}$ Roger was placed at the apex of the pre-existing political hierarchies of the mainland. The dukes of Naples and the Princes of Capua were downgraded to royal vassals. Roger was undeniably pushing the bounds of legitimate action here, and although it had papal backing, Anacletus faced a rival pope $і ̈$ Innocent II $\ddot{I}$ who strove to discredit his opponentô exploits and fanned the flames of South Italian resistance. ${ }^{40}$ Handling Capua, in particular, would be crucial to Rogerô vision of a unified monarchy.

That vision was first articulated in Alexanderôs chronicle with the extended account of the lavish spectacle of the coronation ceremony. ${ }^{41}$ In it, we are told that Roger

Q́ught to be promoted at Palermo, the chief city of Sicily, to the royal dignity since he held not only Sicily, his hereditary patrimony, but also Calabria, Apulia, and other lands $\ddot{i}$ not just obtained by military prowess, but which had devolved to him by right of his close relationship to the preceding dukes. $\hat{O}^{42}$

The status of Capua is notably overlooked, where it fitted into this new political configuration unclear. This obfuscation seems a product of the situation in the early 1130s. The scant evidence from the period following the coronation to the royal occupation of Capua in 1134 suggests that from the start an uneasy and poorly defined relationship existed between the King of Sicily and his new vassal the Prince of Capua. In Capuan charters there is no discernible royal presence: the kingố regnal years are not acknowledged and óoyalôofficials do not appear. The Prince of Capua, along with his own chief vassal Count Rainulf of

\footnotetext{
${ }^{39}$ Roger II, p. 305,

${ }^{40}$ On the schism see I. S. Robinson, The Papacy, 1073-1198: continuity and innovation (Cambridge, 1990), pp. 69-77, 384-6; Loud, Latin Church, pp. 151-4; also on Anacletus II see M. Stroll, The Jewish Pope: ideology and politics in the Papal Schism of 1130 (Leiden, 1987).

${ }^{41}$ Alex. Tel., Bk.II.1-7 pp. 23-6 (Roger II, pp. 77-80)

${ }^{42}$ Alex. Tel., II.2 p. 24 (Roger II, p. 78).
} 
Caiazzo, seems to have been prepared to monitor how events might unfold and to await a đ́egitimateôopportunity to resist Roger. In 1131 both men had acquiesced to Rogerôs request for them to go to Rome with a body of knights to bolster Anacletusôs position there. ${ }^{43}$ But by the summer of 1132 when Roger sought further aid from the Prince of Capua, the latter refused until the king had restored the lands of Avellino and Mercogliano to Rainulf. ${ }^{44}$ The confiscations of land were linked to the actions of Rainulfôs wife, Matilda, the sister of the King of Sicily: Matilda had fled to Rogerô court with their son ostensibly over a dispute with her husband about her dower lands. Robert threatened to withdraw his service to the king if Rainulfôs family and lands were not restored. ${ }^{45}$ The degitimateôopportunity had arisen, and from this point onwards Rainulf and Robert became the emblems of resistance to the monarchy. Falco of Benevento, offering in his chronicle a critique of Rogerôs mainland ambitions (mostly, it must be acknowledged, when they impinged on Benevento), presented Robert of Capua as the embodiment of a libertas menaced by a rex tyrannus. Falco recorded (or crafted?) one impassioned speech in 1132 by Robert to his allies which enthused on the value of freedom and the honour of resistance. ${ }^{46}$ The same author also noted that the prince had suffered the rebuke of improper reward for his previous role in crowning Roger in 1130; as improbable as it was that Robert should have been allowed such a critically symbolic function, the claim itself aimed to augment a wider climate of grievance among mainland elites who feared a similar fate. ${ }^{47}$ On the opposite side, Rogerôs stance notably hardened, at least as Alexander of Telese presents it. He warned Robert that this matter ávas none of his

\footnotetext{
${ }^{43}$ Loud, ántroductionô p. 24; Alex. Tel., II.15 p.30 (Roger II, p. 82); Falcone di Benevento, Chronicon, p. 120 (Roger II, p. 190) 
businessô that it was an excuse not to serve the king, and that if that service was withdrawn óne shall be instantly charged with the crime of perjury. $0^{48}$

Open conflict ensued. The óebelsô led by the Prince of Capua and Rainulf, initially gained the upper hand with a resounding victory over the royal army at the Battle of Nocera in July 1132. ${ }^{49}$ The defeat gave Alexander the opportunity to show the judgement of God in action, as a correction for Roger against the danger of overweening pride. Rogerô humble response to defeat $\ddot{i}$ he confessed just as the model king should that the setback had been deserved $\ddot{i}$ presaged a subsequent wave of success. ${ }^{50}$ In 1133 and 1134 Roger swept all before him. ${ }^{51}$ The óebelsô̂ hope for external aid from Pisa and the German Emperor Lothar did not materialise and Rainulf was even forced into a brief submission in 1134 which saw the king give him the ớxiss [of peace] $\hat{0}^{52}$ Following Rainulfôs reconciliation, the king offered peace to the Prince of Capua. The latter would not be deprived of his honor (óuo non privaretur honoreô if he submitted by August of 1134, but would lose all lands which the king had obtained during their conflict. ${ }^{53}$ If the Prince refused to return, Roger would allow the Principality to be transferred to the princeôs young son, Robert, with the king governing Capua until the boy reached the age of knighthood. But, if no agreement was reached, the dxing would take the principality under his direct lordship and would quite properly receive the homage of all its barons. ôt $^{4}$ The stage had been set for a full annexation of the

\footnotetext{
${ }^{48}$ Alex. Tel., II. 22 p. 33 (Roger II, p. 85).

${ }^{49}$ Alex. Tel., II.29-32 pp. 36-8 (Roger II, pp. 87-9).

${ }^{50}$ Oldoni, đ́RealismoQ̂ pp. 273-4

${ }^{51}$ See Jamison, óNoman Administrationô pp. 246-9.

${ }^{52}$ Alex. Tel., II.63 p. 53 (Roger II, p. 101); Houben, Roger II, pp. 64-5.

${ }^{53}$ Alex. Tel., II.64, pp. 53-4 (Roger II, p. 101).

${ }^{54}$ Alex. Tel., II.64, pp. 53-4 (Roger II, p. 101).
} 
Principality, and what Jamison termed á constitutional change in the position of CapuaQ̂ framed by the legal obligations which bound lord and vassal, the king and the prince. ${ }^{55}$

Here we arrive at the immediate background to Alexanderô encomium of Capua. The Prince, although it is not explicitly acknowledged by Alexander, refused the king $\hat{Q}$ ultimatum. Rogerô theoretical overlordship in this contested territory now needed to be converted into a political, judicial and military reality. How this played out in Capua was even more ideologically critical than how Roger handled the likes of Bari, Salerno, or even Naples. This was arguably the first real test of Rogerôs ability to act as a monarch, annexing a territory that had long been independent, removing its longstanding ruling dynasty, and implementing direct royal rule. In his Prologue, Alexander claimed that Rogerô regal glory was manifest in subduing áo many other territoriesô and in his Alloquium he noted the importance of controlling cities for the maintenance of peace $\ddot{i}$ here at Capua was a palpable demonstration of both. ${ }^{56}$ Roger needed to act as a king at Capua. The encomium and the chapters ï 65 and $67 \ddot{i}$ which bookend it $\ddot{i}$ reflect a construction of Rogerôs royal visage: a divinely ordained monarch, received honourably by his subjects, ruling over the sort of metropolis worthy of royal authority.

Noteworthy here is what occurs in Book II, chapters 65 and 67. In both, Roger received the Laudes Regiae, the liturgical chant which represented a ritual acclamation of a king. ${ }^{57}$ Its performers thus attempted to ingratiate themselves with, and formally acknowledge, the

\footnotetext{
55 Jamison, óNoman Administrationô p. 249.

${ }^{56}$ Alex. Tel., Prologus, p. 3, Alloquium, p. 90 (Roger II, pp. 63, 127)

57 The classic study remains E. H. Kantorowicz, Laudes Regiae. A Study in Liturgical Acclamations and Mediaeval Ruler Worship (Berkeley, 1958).
} 
monarch. First, in chapter 65, Roger was shown visiting the monastery of San Salvatore di Telese whose monks óvent out to meet him with hymns and laudes.ô Roger and the community then performed a set of ritual acts of mutual devotion. Thus formally recognised as a monarch within the monastic house, and spiritually fortified in alliance with monasticism, Roger proceeded to receive the submission of Capua which is recorded as part of the encomium of chapter $66 .^{58}$ But if we skip to chapter 67 , after the submission, Roger was again received ás was proper, by a procession organised in advance of the clerics and all the townspeople, and was led to the archiepiscopal church with hymns and laudesô The liturgical celebration of the triumphal arrival of the king into a city, the Adventus, also replicated the Lordôs ceremonial entry into Jerusalem as king. Thus, the city $\ddot{i}$ in this case Capua Ï was transformed through the Adventus into an earthly Jerusalem, and the monarchôs glory was reflected back onto it. ${ }^{59}$ Alexander then linked this ceremonial acclamation seamlessly to the submission of Duke Sergius, the magister militum of Naples, a city which had ónever been subjected by the sword, and now it seemed to be constrained by word alone. ơ $^{60}$ Rogerô royal metamorphosis was complete. Capua was its stage.

Two interesting features provide deeper resonance to the performance of the Laudes Regiae during these events, and it is tempting to think that Alexander was aware of both. First, for all its detailed coverage of Rogerô coronation ceremony at Palermo in 1130, there is no specific mention of the Laudes Regiae. Surely it was performed. This is suggested by the composition

\footnotetext{
${ }^{58}$ Oldoni, đ́RealismoQ̂ pp. 270-1.

${ }^{59}$ See J. Mann, óAllegorical buildings in medieval literatureô Medium Aevum 63 (1994), p. 206; Kantorowicz, Laudes Regiae, pp. 71-2, 145-6; S. MacCormack, óchange and Continuity in Late Antiquity: the Ceremony of ñAdventusòô Historia: Zeitschrift für Alte Geschichte 21 (1972), pp.721-752; and recently D. Rollason, The Power of Place: Rulers and their Palaces, Landscapes, Cities, and Holy Places (Princeton, 2016), pp. 202-39. ${ }^{60}$ Alex. Tel., II.67 pp. 55-6 (Roger II, pp. 102-03).
} 
of a liturgical Ordo for Rogerôs coronation ceremony and a (probably) late-twelfth century Palermitan formulary of the Laudes Regiae. ${ }^{61}$ But whether it was or was not, its first explicit record in Alexanderôs chronicle is during the events of Capuaôs submission in 1134. Was this another strategy in Alexanderôs carefully crafted narrative, one which emphasised the significance of Capua? In addition, the princes of Capua had enjoyed the unusual privilege of anointing on accession, which in turn suggests that they received a form of ceremonial laudes. ${ }^{62}$ It would seem plausible that Alexander knew of this tradition and was keen to demonstrate Rogerô overriding of it.

If we turn to the encomium itself in chapter 66, around which this set of events pivots, we encounter a passage redolent with messages on the virtue and scope of Rogerô royal authority. The city was a mirror of the monarchy. Alexanderô discussion of Capuaôs multifaceted etymology signposted the cityô ancient heritage and echoed elements of Isidore of Sevilleôs explanation in his Etymologies. ${ }^{63}$ Capuaôs name seemed to signal its exalted rank,

\footnotetext{
${ }^{61}$ R. Elze, ÓTre ordines per lâncoronazione di un re e di un regina del Regno normanno di Siciliaôin Atti del Congresso internazionale di studi sulla Sicilia normanna [Palermo 4-8 dicembre 1972] (Palermo, 1973), 43859; R. Elze, óThe Ordo for the Coronation of King Roger II of Sicily: an example of dating from internal evidenceô in J. M. Bak (ed.) Coronations. Medieval and Early Modern Ritual (Berkeley, 1990), pp. 165-78; Kantorowicz, Laudes Regiae, pp. 158-61. Tounta, óTerror and territoriumô p.149 suggests one possible reason for Alexanderôs failure to note this: rather than emphasising its sacred qualities, Alexander was more interested in presenting the coronation ceremony ás a performance of terrorô in which the kingôs wealth and power overwhelmed the participants and articulated a new political culture.

${ }^{62}$ Kantorowicz, Laudes Regiae, pp. 162-3; For example, see the anointment ceremony of Prince Robert II of Capua in 1127: Falcone di Benevento, Chronicon, p. 90 (Roger II, p. 176).

${ }^{63}$ Isidore of Seville, The Etymologies of Isidore of Seville, trans. S. A. Barney et al. (Cambridge, 2006), Bk.XV.54 p. 304.
} 
the áapital of Campaniaô(áaput Campanieô, imitating Palermo the áaput regniôo ${ }^{64}$ Roger was thus a ruler of áapitalsô in the plural. ${ }^{65}$ Significantly, Alexander concluded the encomium by reminding his audience that Capuâ̂ status as a đ́apitalô had also been augmented by its princely dignity, that is by the Princes of Capua, and thus showed sensitivity to, and respect for, the cityô recent history. Furthermore, the cityôs name was additionally ascribed to an ancient founder, King Capy, again paralleling Alexanderôs discussion of the Sicilian monarchy itself, which suggested that Palermo was once ruled by kings. ${ }^{66}$ Roger was also thus following in the line of ancient monarchs. The Aeneid recorded Capys giving his name to Capua, and Alexander might well too have used this example as a further reminder of Virgilôs labours and the rewards suitable for authors. ${ }^{67}$ The other explanation offered for Capuâ̂ name was linked to its location within a long and wide plain (campus). ${ }^{68}$ This signalled the cityô fertility and grandeur which reflected on its conqueror in a very real way. There was nothing mythical about Capuaôs natural resources and the

\footnotetext{
${ }^{64}$ Isidore, Etymologies, Bk.XV.54 p. 304 also recorded that Campania drew its name from its chief city Capua which, along with Rome and Carthage, was among the three most eminent cities.

${ }^{65}$ The use of the term áapitalôhere is not to be equated directly with modern notions of the word; rather it implies more simply a place of particularly significant political and symbolic power, and where sometimes other mechanisms of government were situated. For a careful and nuanced discussion of the notions of medieval áapitalôcities see P. Boucheron, D. Menjot, P. Monnet, ớormes dâemergence, dôffirmation et de déclin des capitales: rapport introductifô in idem (eds), Les villes capitales au Moyen Âge: XXXVie congrès de la SHMES, Istanbul, 1er-6 Juin 2005 (Paris, 2006), pp. 13-56.

${ }^{66}$ Alex. Tel., II.1 p. 23 (Roger II, p. 78).

${ }^{67}$ Virgil, Aeneid, Bk.10.145-6. Roger II, p. 102 note 118. Isidore, Etymologies, Bk.XV.54 p. 304 noted that the city was built by, and named after, Capys Silvius, a legendary king of the Albani.

${ }^{68}$ See again Isidore, Etymologies, Bk.XV.54 p. 304: ósome say Capua was named for áapacity (capacitas), because its land holds (capere) all produce for living, and others say from the flat (campester) land in which it is situatedô
} 
encomium devotes most of its space to the cityô River Volturno, populated by water mills and spanned by a magnificent bridge, and which dissected a city overflowing with people and all types of merchandise. This echoed standard content within urban panegyric but Alexander shaped it to reflect the real landscape of Capua. Campania was of course known from ancient times as a bountiful land, and Capuaôs hinterland was situated in a fertile alluvial plain. ${ }^{69}$ The late-twelfth century poem of Peter of Eboli, the Liber ad Honorem Augusti, included an illumination of Capua framed by grape vines at the top and ears of corn at the bottom, and spoke in similar terms of an:

Ancient city, most rich in its own field, Mother of resources, fortunate in its bishop, full of men, A land that flourishes with fruitfulness, and in autumn is prolific, Its poplar tree, which loves its river, is wedded to the vine, The same [poplar] embraces ordered elms, The inhabitant is proud that the grape pours forth the unmixed wine, The land having been thrice sewn, it is sewn three times, gives three answers to the farmer, Three times under a new sun does the land weigh out its seeds. ${ }^{70}$

And the encomium notes too the magnificence of the cityô built landscape: its extensive layout, fortified by walls and towers (which were again noted in Peter of Eboliôs poem), its suburb connected by that large bridge of ávonderful workmanship.ôCapua appears as a city worthy of a monarch and integral to the monarchy. It should not be forgotten also that Capua was only $4.5 \mathrm{~km}$ north-west of Capua Vetere, the famed Roman city that was finally abandoned in 841. In the Middle Ages, Capua Vetere, especially its amphitheatre, served as a

\footnotetext{
${ }^{69}$ G. A. Loud, Church and Society in the Norman Principality of Capua. 1058-1197(Oxford, 1985), pp. 13-17;

I. Di Resta, Capua (Bari, 1985), pp. 3-4.

${ }^{70}$ Petrus de Ebulo, Liber, 121v lines 773-80 (this is joint translation produced by I. S. Moxon, G. A. Loud and myself); illumination at 122r; M. DôOnofrio, ócapuậ in G. Musca (ed.) Itinerari e centri urbani nel Mezzogiorno normanno-svevo : atti delle decime giornate normanno-sveve, Bari, 21-24 ottobre 1991 (Bari, 1993), pp. 290-1
} 
quarry of materials for ónewôCapua; consequently ancient spolia was reutilised throughout the urban landscape, most notably in the cityôs cathedral. ${ }^{71}$ This antique history embedded within the city combined with its Lombard heritage and strategic location to confer on Capua a prominent status within the new monarchy. Capua was the first major stop south of Rome on the Via Latina, at the key crossing point on the River Volturno. Embassies, pilgrims and travellers of all type were funnelled through the city $\ddot{i}$ it became a fulcrum for communications and the gateway to the monarchy, hosting numerous hospitals and travel lodges in its suburbs. ${ }^{72}$ No wonder that around 1234, Frederick II chose to build his magnificent classicizing triumphal gate, the Porta Federicana, on the cityô Casolini bridge, to serve as a suitably imposing entrance point to the kingdom. ${ }^{73}$

Rogerô direct takeover of Capua was therefore a crucial moment in the formation of the kingdom of Sicily. It was an event which one of our most significant contemporary observers deemed pivotal and deserving of an urban encomium to relay its importance. The historical narrative of events after 1134 might show that resistance continued until 1139, that Roger suffered setbacks, particularly during the imperial invasion of 1137 when Rainulf, once again in rebellion, was invested as duke of Apulia by the pope, and that other venues (Naples, Salerno, Bari, Mignano) staged episodes of critical significance to the fledgling monarchy in the late-1130s. ${ }^{74}$ But, Capuaôs submission in 1134 arguably established a watershed from

\footnotetext{
${ }^{71}$ DôOnofrio, óCapuaQ̂ 269-91; J. Meredith, órhe Arch at Capua: the strategic use of spolia and references to the Antiqueâ in W. Tronzo (ed.) Intellectual Life at the Court of Frederick II Hohenstaufen (Yale, 1994), p. 115; M. Greenhalgh, The Survival of Roman Antiquities in the Middle Ages (London, 1989), p. 24.

${ }^{72}$ Oldfield, City and Community, p. 221 and note 258; Oldfield, Sanctity and Pilgrimage, p. 188; G. Bova, La vita quotidiana a Capua al tempo delle crociate (Naples, 2001), pp. 81-2.

${ }^{73}$ DôOnofrio, óCapuaô pp. 286-9. Meredith, óThe Arch at Capuaô 109-26.

${ }^{74}$ See Jamison, óNorman Administrationô pp. 251-6.
} 
which there would be no retreat. If the coronation of 1130 displayed the concept of monarchy, and early negotiations with mainland cities had showcased an emergent blueprint for relations between king and subject, the submission of Capua arguably represented the first unequivocal manifestation of the magnitude and capabilities of royal power in action. ${ }^{75}$ As Reinhard Elze noted, the coronation made Roger a king, but he had yet to possess a regnum. ${ }^{76}$ Control of Capua was central to realising the regnum, for other evidence indicates that Rogerô capture of Capua in 1134 encouraged a more ambitious royal strategy. Clementi would seem to be correct, that the surrender of Capua had been pre-negotiated and that the bargain struck allowed the Capuans áo regulate their own affairsô in return for the cityôs more complete integration within a royal administrative superstructure. ${ }^{77}$ The latter reflected a crucial transition; it saw the first definite órganisation of provincial governmentôby the new king, although the poor documentation for Apulia cannot rule out an earlier organisation of that region in the winter of $1133-4 .^{78}$

We can at least say for certain that, by 1135 , Roger had installed high-level royal figures to oversee the government of the Principality of Capua, the likes of the royal chancellor Guarin and the Emir John. ${ }^{79}$ Moreover, in August 1135, he had granted óy bannerôthe Principality of Capua to his third son, Anfusus. ${ }^{80}$ It was also at Capua in 1135 that the first certain evidence for the appointment of proto-mainland royal justiciars appears. These officials

\footnotetext{
${ }^{75}$ See for example the important charter of privileges given by Roger II to Bari in 1132: P. Oldfield, óBari Charter of Privilegesô

${ }^{76}$ Elze, óOrdoô p. 167.

${ }^{77}$ Clementi, óHistorical commentaryô pp. 315, 329-30.

${ }^{78}$ Jamison, óNorman Administrationô pp. 244, 248.

${ }^{79}$ Alex. Tel., III.6 p. 62 (Roger II, p. 105).

${ }^{80}$ Alex. Tel., III.28 pp. $74-5$ (Roger II, p. 116); Clementi, óHistorical commentaryô p. 263.
} 
would be integral to the functioning of the monarchy in the later twelfth century and the first proto-justiciars were the new Archbishop-elect of Capua, William of Ravenna, an outsider perhaps deemed to be a balancing, neutral figure in the principality, and a local Aversan baron named Aimo of Argentia who had previously witnessed charters of the prince of Capua. ${ }^{81}$ Similarly, a certain Joscelin, who appears to have been the pre-existing chamberlain in the principality, was promoted to govern, as its procurator, Capua and its region. These appointments were made at a special assembly in September 1135, held at Capua, and which involved a procession of the cityố clergy and populace. ${ }^{82}$ Here the cityôs new archbishopelect was introduced, an event which Loud suggests was álearly stage-managed by King Roger, and was an integral part of his takeover of the hitherto independent principality. $0^{83} \mathrm{At}$ the same time the new prince Anfusus was presented, to whom all the barons of the principality of Capua formally swore fealty. Finally, for the promotion of justice, Roger established the aforementioned William, Aimo and Joscelin in their posts. Jamison and Takayama both suggest that this grand assembly paralleled Rogerô Peace of Melfi, a comparable gathering which in 1129 also set out to promote peace and justice in Rogerô newly acquired Apulian territories. But on this later occasion an administrative restructuring

\footnotetext{
${ }^{81}$ On the archbishop-elect see Loud, Latin Church, pp. 229 and n. 161, 271-2, 535-7; On Aimo see Roger II, p. 118 n. 155, and Loud, Capua, pp. 163-4. H. Takayama, The Administration of the Norman Kingdom of Sicily (Leiden, 1993), pp. 62-3, 77-8.

${ }^{82}$ Alex. Tel., III.32 p. 77 (Roger II, pp. 118-19); Joscelin was termed a royal chamberlain in the Chronica Monasterii Casinensis, ed. H. Hoffmann, Monumenta Germaniae Historica Scriptores, 34 (Hanover, 1980), VI.98, p. 558; Jamison, óNorman Administrationô pp. 279-80, 306-07, 375, 383-4, 397; Oldfield, City and Community, p. 68.

${ }^{83}$ Loud, Latin Church, pp. 271-2.
} 
was set up to implement a general peace. ${ }^{84}$ This marked the formal end of Capuan independence.

Thus, a mixture of new and old officials was relied upon, and Rogerôs ability to simultaneously implement new administrative offices and co-opt locally influential individuals projected a powerful statement of authority. It was an approach which would become the standard after 1139 and it was grounded in events at Capua in 1134-35. Alexander of Telese, close to these events in both time and space, clearly saw the multilayered significance for Capua and hence framed it within an encomium. Indeed, shortly afterwards, by 1136 , we see a re-ordering of the royal title itself to take the form that would be the most common for the remainder of the twelfth century: Rex Sicilie, ducatus Apulie et principatus Capue. ${ }^{85}$ The title included Capua for the first time. It respected the kingdomô unique composite history around which new administrative sub-divisions would emerge

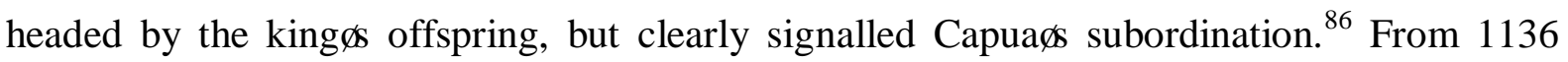
private charters issued at Capua also carried the regnal years of Roger and Prince Anfusus. A document of September 1136, for example, was dated ôn the time of our Lord Roger, by grace of God glorious King of Sicily and Italy and in the first year of the Principate of his son the glorious Prince Anfususô ${ }^{87}$ It is impossible to gauge truly the loyalty of the Capuans to

\footnotetext{
${ }^{84}$ For the Peace of Melfi see Alex. Tel., I.21 pp. 18-19 (Roger II, pp. 75-6); Jamison, ÓNorman Administrationô pp. 238-43; Takayama, Administration, p. 62;

${ }^{85}$ Rogerii II Regis Diplomata Latina, no. 43 p. 120; no. 48 p. 135; Jamison, óNorman Administrationô p. 266; Houben, Roger II, p. 67.

${ }^{86}$ Jamison, óNorman Administrationô p. 247.

${ }^{87}$ Le pergamene di Capua, ed. J. Mazzoleni, 3 vols (Naples, 1957-8), vol. 2, no. 8 p. 16; see also vol. 1, no. 27, p. 67. There is also a Capua charter, of problematic dating, but seemingly issued in October 1134 áemporibus domini nostril Roggerii Dei gratia Sicilie et Italie regis gloriosissimiô This would represent the earliest direct
} 
this new political situation. An attempted recapture of the city in 1135 , by Rainulf and Sergius of Naples, failed. Their hopes that Capua would be betrayed to them by those inside still faithful to the prince were dashed by Rogerôs chancellor, Guarin, who exiled to Salerno any suspected inhabitants. ${ }^{88}$ Alexanderô account ends with Capua firmly under royal control. Falcô̂̊ chronicle, which extends the narrative of events, showed the cityôs restoration to the prince by Lotharô imperial forces in $1137 .{ }^{89}$ But once those imperial forces became overstretched and withdrew from southern Italy, Roger II returned from the safety of Sicily and soon re-established control over large swathes of the mainland. Royal power had by this stage crystallised to a point where the king could wait out foreign invasion and internal rebellion before rebuilding from where it had left off. Capua was soon back in royal hands and Prince Robert II forced into long-term exile at the German court. ${ }^{90}$ Falco covered Rogerô furious response: the city was given over to flames, and women, nuns and churches all maltreated. ${ }^{91}$ If there is a suspicion that Falcoôs account might have been embellished to defame the king, it should be noted that it received support from the Montecassino Chronicle

reference to Rogerôs rule in the city, and one soon after its capitulation: Codice diplomatico verginiano, ed. by P. M. Tropeano, 13 volumes (Montevergine, 1977-2000), iii. 48-51 no. 213.

${ }^{88}$ Alex. Tel., III.7 p. 63 (Roger II, p. 107).

${ }^{89}$ Falcone di Benevento, Chronicon, p. 178 (Roger II, p. 217); The Saxon Annals claim that Prince Robert gave Duke Henry of Bavaria, the leader of the imperial force approaching Capua, 400 talents to leave the city unharmed: Roger II, p. 274. The Montecassino Chronicle claimed that once the Capuans saw the local barons side with the imperial army they decided to surrender to Duke Henry and Prince Robert: Roger II, p. 291. Oldfield, City and Community, p. 64, 71-4.

${ }^{90}$ Only briefly, in 1155-6, would Robert II regain control of Capua, his princely capital, when widespread revolt ï aided by external powers $\ddot{i}$ struck the Kingdom of Sicily. But again, he was rapidly ousted once royal authority was restored in 1156 by William I: see Oldfield, City and Community, pp. 108-11.

${ }^{91}$ Falcone di Benevento, Chronicon, p. 196 (Roger II, p. 225). 
which recorded that Capua was set on fire. Such violent punishment would indicate the cityôs particular importance to the monarchy and the need to deter further rebellion. ${ }^{92}$

Capua rapidly became an integral part of a new aspiring monarchy. Symbolic, strategic and political imperatives of the very highest importance to Roger II were all bound up within the cityô role in the kingdom. Its direct submission to Roger in 1134 commenced a new phase in his formation of the Kingdom of Sicily, and, despite setbacks, it represented a critical advance that would not be reversed. Alexander, an acute, highly invested observer who was keyed into important information networks, understood this, and opted to emphasise the event through an urban encomium. This encomium showcased a ruler acting as king, welcomed by his new subjects, both lay and religious, and receiving the Laudes Regiae. It presented a city that functioned in its own terms as a ćapitalô ancient, extensive and bountiful just like Palermo, and consequently worthy of governance by a monarch. From 1134 Roger became King of Capua the royal city.

\footnotetext{
${ }^{92}$ Roger II, p. 293.
} 